ISSN: 0213-3563

https://doi.org/10.14201/azafea2020226783

\title{
THOUGHTS ON PAIN. FRIEDRICH NIETZSCHE AND HUMAN SUFFERING
}

\section{Consideraciones sobre el Dolor. Friedrich Nietzsche y el Sufrimiento Humano}

Paolo SCOLARI

Università Cattolica del Sacro Cuore - Milano

Recibido: 14 de enero de 2019

Aceptado: 26 de mayo de 2020

\begin{abstract}
In Friedrich Nietzsche, the autobiographical theme of illness is inseparable from the philosophical problem of pain. While he reflects on his condition of the ill person, Nietzsche oscillates the human being like a pendulum. He defines him as the ill animal, as the most melancholic animal, but also as the most courageous and most used to pain, as the happiest animal who suffers so profoundly that he must invent laughter. Parallel to these anthropological writings, Niterzsche presents bold allegations against the desperate attempts, public or private, that the human being makes to remove the pain from its own existence or live as if it never existed. The hypocritical justifications, religious or secular, for those who which to find a sense of absurdity in suffering may meet with the comfort of modern society (science, politics, religion), who desperately take risks to mould a humanity without any evil. By considering his personal experience of illness as crucial, Nietzsche desires to experiment up to the point thought can resist and in which direction it takes whenever it is under the pressure of evil. His investigation shows how the negative cannot be eliminated from existence. However, it constitutes a necessary ingredient without which tears would signify too much joy, and one would never arrive at the laughter.
\end{abstract}

Key words: Nietzsche; suffering; illness; sickness; evil; pain; justifications; hypocrisy; ethics. 


\section{RESUMEN}

En la filosofía de Friedrich Nietzsche es inseparable el tema autobiográfico de la enfermedad del problema filosófico del dolor. A la vez que reflexiona sobre la condición de la persona enferma, Nietzsche hace que el hombre oscile como un péndulo: lo define como el animal enfermo, como el más melancólico de los animales, pero también como el más bravo y más habituado al dolor, y como el animal más feliz, que sufre tan profundamente que debe inventar la risa. De modo paralelo a estos escritos antropológicos, Nietzsche denuncia enfáticamente los intentos desesperados, públicos y privados, que hace el hombe para remover el dolor de su propia existencia o para vivir como si nunca hubiese existido. Las hipócritas justificaciones, religiosas o seculares, de aquellos que encuentran un sentido absurdo en el sufrimiento, se encuentran con el comfort de la sociedad moderna (ciencia, política, religion), donde desesperadamente se toman riesgos para modelar una sociedad sin mal. Al cosiderar como crucial su experiencia personal con el dolor, Nietzsche desea experimentar hasta el punto en que resista el pensamiento y en la dirección que éste tome cada vez que se encuentra bajo la presión del mal. Sus investigaciones muestran cómo es imposible eliminar lo negativo de la existencia, pues constituye un necesario ingrediente sin el que las lágrimas significarían demasiada alegría y nunca se llegaría a la risa.

Palabras clave: Nietzsche; sufrimiento; enfermedad; malestar; mal; dolor; justificaciones; hipocresía; ética.

\section{NietZsche AND THE MAN, THE ILl ANIMAL}

In the thought of Friedrich Nietzsche, the autobiographical theme of illness has, at its core, the philosophical problem of pain. While he reflects daily on the ill person's condition, Nietzsche oscillates the man like a pendulum. In one of his posthumous fragment he defines the man as "the most melancholic and most happy animal who suffers so profoundly that he must invent laughter", and in Zur Genealogie der Moral the man is "the ill animal" but also as "the most courageous and most used to pain" (GM, III). Nietzsche seems to be entertained no end by playing around with these definitions, almost as if he is making fun of Aristotle ${ }^{1}$.

1. The article cites Nietzsche's works using the following abbreviations: $\mathrm{AC}=$ The Antichrist; BGE = Beyond Good and Evil; BT = The Birth of Tragedy; D = Daybreak; $\mathrm{EH}=$ Ecce Homo; GM = On the Genealogy of Morality; GS = The Gay Science; HH = 
These two later quotations that go on to construct the tracks on which his reflections on badness and suffering will move, mark the area in which the decisive 'match' of the health of humanity is discussed. The first displays a Nietzsche who is always trenchant and blazing in its ability to conjure humans' humanity in few words. The highlight of the determinate article is original ("the ill animal") and shows that man is a unique animal who can define himself as being ill. The second suggests the image of a human being who tolerates pain with courage, arriving, just thanks to this journey of pain, to embark on a voyage leading to internal transformation.

Nietzsche's lifelong illness prompted him to develop the philosophical problem of pain and its relationship with thought. Taking advantage of his condition as a constant sufferer, Nietzsche strived to understand which directions human thought can take whenever it is "subjected to the pressure of evil" (GS, Preface for the second edition, 2). The first is a hypocritical direction, represented by man's attempts to remove pain from his life. Nietzsche denounces all justifications made to provide at all costs a meaning for suffering, and which converge with the modern welfare society that dares to fashion humankind without evil. The other direction, however, is that of those who are not afraid to listen to suffering. Reflecting on his own personal situation, Nietzsche outlines the traits of human beings who reach out towards the mystery of existence and, shaken by the experience of pain, come to abandon their certainties and adopt a more critical view of themselves.

"Every man is a medical history", recites a posthumous fragment. Indeed, Nietzsche himself is the first to notice "his own story is the story of an illness and also of a healing" ( $H H$, Preface, 6) - and this is not only true for him but for everyone who experiences suffering up close. This experience of pain - so intimate that it seems complicated to express in words - does not cause one to be locked up inside of oneself but rather serves to introduce a discussion on one's subjectivity and as an occasion for a moral adventure into the profundities of one's existence.

Human, All Too Human; TI = Twilight of the Idols; UF = Unpublished Fragments; and $\mathrm{Z}=$ Thus Spoke Zarathustra. 


\section{ILLNESS: THE OTHER NAME OF NIETZSCHE}

In the essay Nietzsches Philosophie im Lichte unserer Erfabrung Thomas Mann is lapidary in affirming that Nietzsche "also has another name: illness" (Mann, 1948). After all, it is practically impossible to look at Nietzsche's life without encountering his illness (cf. Fallica, 2002, p. 101). The two aspects overlap so perfectly that they coincide, to such a degree as to prompt medical historian Heinrich Schipperges to define in no uncertain terms Nietzsche's whole existence as a history of the illness (cf. Schipperges, 1985, pp. 215-222; Schipperges, 1975, pp. 93-100).

Apart from the deranged decline into madness that characterised his last decade, the whole life of Nietzsche appears indelibly marked by suffering. From his letters, we learn that during adolescence, he often suffered from violent attacks of nausea and vomiting, dizzy headaches and devastating collapses, annoying stomach, and intestinal problems, hypersensitivity to light, and decreased vision. This extremely delicate state of health was to accompany him throughout his life, gradually worsening year by year. From an early age, it confined him to bed for days, in complete solitude in the darkness of his little room, without allowing him to read or write. In his early thirties, it forced him, much to his regret, to suspend his lectures at the University of Basel and resign from the academic scene, taking a sort of early retirement after which, he tended to live in places with climatic conditions that were more favourable than those of the city and to adopt an increasingly healthy diet. Finally, his illness brought about mental degeneration and complete inactivity for the last eleven years of his life, before his death in 1900, at fifty-five. Living on the borders of hypochondria, Nietzsche perceived his illness as a sword of Damocles continually hovering above his head. The fact that his father Carl Ludwig had died at the age of thirty-six due to severe degenerative brain disease caused Nietzsche great distress, obsessively plagued by the thought that he too would die of the same pathology at that age, if not earlier (cf. Nietzsche, 1975; Janz, 1994; Nuccitelli, 1996).

In his monograph Friedrich Nietzsche in seinen Werken, Lou Salomé focuses on the "close connection" between Nietzsche's "suffering" and his intellectual development, emphasizing the propulsive role of pain and "the influence that the sick man's states of mind had on his thought". As Domenico Fazio points out in the afterword to the Italian edition of the book, Nietzsche's writings were regarded by Salomé as an excellent autobiography of suffering. As someone who perhaps knew him far better than anyone else, 
she came to define his existential parable as a real "story of pain" (AndreasSalomé, 1894; cf. Fazio, 2009, pp. 206-207, 209).

Foremost among any interpretation, however, is that of Nietzsche, who speaks of his pathological experience philosophically and presents it in a hermeneutical guise. His reflections on his personal valetudinarian condition transcend the annalistic aspect, thus enabling a broader interpretation in which pain becomes the key to comprehending human existence. He was the first to realise that "his story - the story of illness and healing - is not just his own personal story”, but closely concerns all men (HH, II, Preface, 6).

\section{Giving pain a voice. Philosophising}

In the preface to the second edition of Die fröbliche Wissenschaft, Nietzsche places the human being in a condition of precarious balance. Halfway between acceptance and denial of pain, man must manage to transform it through the driving force of his own existence without getting caught up in the loopholes of its justification. Nietzsche perceived his pain as an oppressive "tyranny" from which it seemed impossible to free himself, except by being "overthrown" by another, more tenacious "tyranny" - that of "pride which rejects the conclusions of pain". In the human soul, these two despots seem to be constantly at war: on the one hand, pain, which puts man with his back against the wall, and on the other pride in his own self, which refuses to allow him to be subdued and rails against the suffering, declaring that since "this world is illusion and contradiction; therefore there exists a world that is real and without contradiction" (GS, Preface for the second edition, $1 ; U F, 8[2])$.

Nietzsche was aware that the questions sparked by pain all too often find hypocritical answers. The pressure of evil forces man to seek palliatives to ease it or radically remove it from their lives, allowing them to carry on as if it did not exist. Nietzsche was able to unmask these illusions because he himself has been through the forge of pain. Only "after such self-questioning, self-temptation, one acquires a subtler eye" for the behavior of his fellow men. "Every philosophy that ranks peace above war, every ethic with a negative definition of happiness, every metaphysics and physics that knows some finale, a final state of some sort, every predominantly aesthetic or religious craving for some Apart, Beyond, Outside, Above...”. All this permits the question of whether all philosophizing has, up until now, had not to do with the search for 'truth' but something quite different and whether, for better 
or worse, "it is not the sickness itself that inspired" human thought. Behind the incessant search for bright, comfortable places, whether metaphysical or earthly, there is always the desperate desire to escape from a deep state of anguish. "Suffering thinkers are led and misled" to "involuntary detours, alleyways, resting places, and sunny places of thought ... the sick body with its needs unconsciously urge, push and lure the mind - towards sun, stillness, mildness, patience, medicine, balm in some sense" (GS, Preface for the second edition, 1).

In his personal story, Nietzsche retraced the steps of this twofold experience. First of all, he aimed to "do away with all the deductions that struggle to grow like poisonous mushrooms from pain, from disappointment, from tedium, from isolation and other swampy terrains", which do nothing but "generate in the long run something worse than that which had to be eliminated along with them" (GS, Preface for the second edition, 1 ; $H H$, II, Preface, 5). Once the ground was cleared, he intended to give voice to the pain. It is precisely from this liberated pain, in fact, that philosophy springs. It is actually these very "states of suffering themselves that philosophize" - "as is the case with all sick thinkers" (and perhaps, as Nietzsche believed, it is precisely these who "prevail in the history of philosophy"), pain is not merely an end in itself, but for the sole fact of becoming manifest always presents a request for meaning. It creates the problem and urges the human being to ask questions continually. "Subjected to the pressure of evil, thought" never ceases to ask itself why (GS, Preface for the second edition, 2).

\section{Deny, alleviate, Justify. The hypocritical Redemption of Pain}

In the third section of Zur Genealogie der Moral, Nietzsche reconstructs the logic behind the tendency for the men of Western civilisation to justify the pain. Since "suffering" has always been their "biggest question mark", for the sake of a quiet life, they have tried in every way to find a remedy for it. Furio Semerari comments on this passage from Nietzsche's text, saying that, according to Nietzsche, humankind is only able to accept pain if there is a meaning for it; "meaningless evil" is not conceivable and, therefore, must be "justified" (GM, III, 17; UF, 10 [21]; cf. Semerari, 1993, pp. 79-80).

For Nietzsche, the redemption of pain takes three different forms: denial, alleviation, and justification - a threefold face with one aim: to remove pain from existence. The schemes of elimination lead to the distortion of the es- 
sence of pain and the loss of its specific importance. It is likened to a 'bump in the road,' difficult but surmountable. "Pain is illusion, error, nothing but the error", as Socrates would say, quoted by Nietzsche in Die Geburt der Tragödie (GM, III, 12; BT, 15). In this case, "as soon as the error is recognised, suffering must disappear" - the intellect identifies the malformation and removes it surgically. As in a dialectical game, evil is nothing but the negative pole that is resolved in the "absence of pain", which becomes "the highest good ... that has to be valued positively and found to be the positive itself" (GM, III, 17).

In order to mitigate pain and not feel its tragic positivity, it is hidden behind more pleasant, appealing names. Humans are just not able to live with this conundrum. Since "pain hurts", it is unbearable and therefore "adorned with such inoffensive names... means of consolation ... "to refresh, soothe and narcotize". It is above all in Christianity that Nietzsche sees this logic in action. In Zur Genealogie der Moral, he describes "the ascetic priest" as "a doctor who combats suffering, who narcotizes and relieves pain, consoling and refreshing". Only this priest can "chase away the dark sorrow of man", giving "a religious interpretation and "justification" to his ills. "He exploits suffering and finally comes to sanctify it", succeeding in giving it meaning: the suffering man can now "be informed of the 'cause' of his suffering", which becomes the "way to being blessed". Nietzsche completely rejects such dynamics, on the strength of having learned under a teacher like Schopenhauer, who first taught him to take "the sufferings of humanity seriously" and to expose "the antidotes against these sufferings" and "pillory the unheard-of quackery with which men, even up to our own age, and in the most sublime nomenclature, have been wont to treat the illnesses of their souls" (GM, III, 17, 20; D, 52; BGE, 61; UF, 10 [21], 14 [89]).

The justificatory ritual seems to be inherent to human existence, divided between the appearance of evil without reason and an endless search for meaning. Nietzsche points out that the most distressing thing for man is "to suffer without knowing why": he who finds himself in this condition is "eager to find reasons, remedies, and narcotics that give relief" to his suffering (GM, III, 20). In his reinterpretation of Nietzsche, Gilles Deleuze argues that human beings are unable to eliminate pain entirely and therefore internalize and spiritualize it, seeking a new meaning that can be given to it (Deleuze, 1992, pp. 156-158). As Nietzsche says in the Genealogie, humans share the anguish of not being able to conceive the idea of meaningless suffering and "need an explanation" that will allow them to live serenely. In fact, 
"what really causes them to rebel against suffering is not suffering itself, but the absurdity of suffering. The fact that the despairing question "why do we suffer?" remains unanswered is the curse that up until today has continued to plague humanity". Right from the beginning, "suffering has always posed the problem of its cause", carrying within it a "claim to meaning". The human being must at all costs find "a meaning, a 'reason' for suffering”, he longs to be "saved" from the illogicality of suffering, to be "no longer a leaf in the wind, a plaything of absurdity, of 'nonsense." So he immediately runs for cover, "interpreting" and "filling" this "enormous emptiness" with something that might be able to account for "absurd suffering". After all, such a man thinks to himself, "any meaning is better than no meaning at all" (GM, III, 20).

According to Nietzsche, the process of justification is fulfilled both in a religious and a secularized context. On the one hand, "Christians have transferred to suffering an entire secret machinery of salvation", and on the other, "in past ages, men have been able to explain every kind of suffering based on the spectators of suffering". To the former an ethereal, eternal salvation, to the latter a veritable show, both "cruel" and "edifying". The historical and cultural contexts may change, but the justificatory mechanism is the same. Nothing can remain unexplained and escape human rationality, but everything must happen for some salvific purpose or be totally revealed and observed, and therefore rendered intelligible. Men of every era have strived to "deny and remove from the world suffering that is hidden, undiscovered, without witnesses" through "the invention of gods and intermediate beings of every height and depth, something, that is, that also sees in the dark and does not easily let an interesting display of suffering escape". They have come to the point of eradicating the meaning of existence from existence itself and placing it elsewhere, thus ultimately losing a real relationship with life. "Thanks to such inventions and stratagems they have justified life and its 'evil,' depriving it of its 'enigmatic' and 'problematic' character" (GM, II, 7; III, 28; GS, 13; AC, 23; cf. Aurenque, 2013, pp. 54-55).

\section{Cities of Well-Being. “We have inVented happiness”}

Nietzsche intercepts the public implications of the justification of pain and criticizes the hedonistic cities of well-being, the purpose of which is collective happiness. It is not without reason, in fact, that Cristiana Senigaglia 
repeatedly points out that the Nietzschean reflection on suffering always takes on social and political significance (Senigagglia, 2011, pp. 91, 94-95, 97).

"Suspicious of any excessive well-being" $(D, 18)$, Nietzsche exposed the hypocrisy that underlies modern society, which is not "seeking 'more happiness' but 'less pain." Modernity rides the wave of utilitarianism, stubbornly striving to pursue "as much pleasure as possible and as less displeasure as possible". Joy and sorrow are inversely proportional: the purpose of the society is precisely to minimise pain, raise the happiness index to exorbitant levels, to the point of considering it as an "'absence of pain for all'" (UF, 1971, 3 [25], 3 [102], 3 [144]; cf. Losurdo, 2004, pp. 34-39).

In the city, there seems to be no more room for pain. It is the modern metropolis, inhabited by the "Last man" of Also sprach Zarathustra (Vorrede), a prototype of the massified human beings who "invented happiness" and "left the districts where life was hard", and to whom "becoming ill is always a fault" (Z, Preface, 5).

The society of the last men sets universal well-being as the highest value and is therefore no longer able to recognise itself as sensitive to pain. It seeks instead to minimize it, hide it, even eliminate it in order to pursue comfortable and convenient pleasure. In a bourgeois climate of Hegelian-positivist optimism, confidence in the rationality of history, in the future, and in progress is pushed to the extreme. Everything goes, without the slightest doubt, in the only possible direction, towards a tomorrow that will undoubtedly prove better than today. A naive mentality, according to Nietzsche, where there is a will to numb existence and "make it painless" (UF, 1971, 3 [151]). The city "sets itself to carrying out tasks geared to eliminating pain". Its inhabitants go so far as to evaporate all the aspects of pain relating to the body, transforming it into an abstract and harmless thought that does not overly disturb their lives. "Pain is hated much more than formerly; indeed, one can hardly endure the presence as a thought and makes it a matter of conscience and a reproach against the whole of existence" (HH, II, 187; GS, 48; cf. Die Philosophie im Tragischen Zeitalter der Griechen).

\section{Comfortable life. Religion, SCience, Politics}

In the city of men, Nietzsche unmasks the three protagonists of justification: religion, science, and politics. From every area of society, man is 
assailed by tempting and confusing offers of comfort. Today's city-dwellers no longer feel pain, flattered by the pompous rites of the public, religious or secular, sphere, which strives to outdo itself in giving them the promised land of low-cost happiness.

It is religion, first of all, that attempts to build a society of well-being. Nietzsche dedicates a whole aphorism in Die fröhliche Wissenschaft to harshly denounce the "followers of the religion of compassion" who want to eradicate pain from humanity. They begin by "noting the condition of suffering" of the single individuals and, concentrating on this personal level, then give an initial "superficial interpretation". While exposing this "unhappiness" in order to "help" their fellow men to overcome it, "they have no thought that there is a personal need for misfortune". "They strip other people's suffering of what makes it truly personal, thus depreciating their value and their will. They know nothing about the personal unhappiness of others. At the same time, they do not think "that terrors, impoverishment, midnights, adventures, risks and blunders are as necessary as their opposites, or that, indeed, that the path to one's own heaven always passes through the voluptuousness of one's own hell”. They blindly follow their faith, "the religion of piety", which "commands them to help, and they believe they have helped best when they have helped most quickly". They "refuse to let their suffering lie on them even for an hour and instead constantly prevent all possible misfortune ahead of time". They "experience suffering and displeasure as evil, hateful, deserving of annihilation". Pain is considered a veritable "defect of existence" to be done away with as quickly as possible (GS, 338).

Nietzsche exposes the behavior of these religious followers, digging out from behind the disguise of "pious religiosity another religion", which he ironically called the "religion of a comfortable life". This is the "mother" who guides their pious and benevolent behavior. Dropping the charade, the compassionate prove to be "peaceful, good-natured people who know little about the happiness of man". Behind their flawless and selfless conduct is concealed the hypocritical attitude of those who are only close to the suffering of others because they cannot endure the dangers of existence. Or, even worse, for their own personal gain $(G S, 338)$.

"Modern science", unwilling to be out-paced by religion, follows in its own way the same path of the elimination of pain. In its "secular" promises, Nietzsche hears the echo of those offered by religion. Science also, in fact, "has as its goal the least possible pain, the longest possible life, a sort of eternal blessedness" ( $H H, \mathrm{I}, 128)$. 
Lastly, politics respond to religion's and science's dual attempt by making the slogan of the absence of suffering into an instrument of propaganda. According to Nietzsche, politics manipulate people's suffering, triggering a twofold ploy that is very similar to the one practised by religion. On the one hand, it stimulates "participation in the pain of all those who suffer", and on the other, it regards "suffering itself as something that must be eliminated" (UF, 1974-1977, 37 [176]). Though at first glance, these two approaches may seem to be discordant, their goal is the same: to do away with suffering. While the former focuses on compassion towards human beings, empathizing with the inevitability of the suffering that unites them, the latter suggests the means, i.e., its radical elimination. The proposed politics is that of solidarity with the suffering human geared to eliminating the pain itself. This is contradictory solidarity, which takes away what it is supposed to be guaranteed, and also hypocritical because it exploits suffering in the knowledge that it will eventually have to negate it.

\section{Convalescent thoughts}

Nietzsche places in antithesis the justification and the heeding of suffering. Die fröbliche Wissenschaft is the work in which the Nietzschean hermeneutic idea of thought that is not afraid to encounter suffering is most energetically affirmed. Here Nietzsche objectively examines his own existence, allowing all his suffering to 'decant' and deposit in fragments that unsettle and deeply provoke his fellow human beings. After all, when he wrote this book in 1882, he was just emerging from one of the most painful periods of his life. Nietzsche himself defines the book, in fact, as a "lived experience" (GS, Preface for the second edition, 1), which is autobiographically tattooed with the pathos of a man who has achieved an unexpected state of health and can finally put on paper his arduous journey of the spirit. In the preface to the Italian edition, Giorgio Colli points out how in Die fröbliche Wissenschaft the entire book is steeped in illness and recovery and offers a glimpse of the author as balanced between the recovery of his health and the suffering he leaves behind, but also clearly reflecting on how this acute suffering has affected his existence. The atmosphere one perceives through the aphorisms is that of the convalescent who does not forget the suffering his illness caused him, but manages to take stock of it and, through it, lead his thought towards new horizons Colli, 1980, pp. 97-98, 103-104). 
Nietzsche appeared to be aware of the fundamental role that this book played in his lifetime, so much so that four years later, in the autumn of 1886, while in Ruta (Genoa), he was writing the preface to the second and extended edition, he recalled that very period of great suffering. Thus the reflections of the cured Nietzsche intersect with those of a man who, despite everything he had gone through, does not deny his precarious state of health but rather comes to internalize it and make it completely his own. Karl Jaspers says in his book Nietzsche, Einfübrung in das Verständnis seines Philosophierens, Nietzsche shows that he is constantly grateful to the illness for its crucial contribution to his spiritual development, and with remarkable sensitivity uses it as a source from which to draw philosophical thoughts on human suffering (cf. Jaspers, 1996, pp. 114, 116).

Nietzsche manages to maintain a fruitful tension between sickness and health, keeping them vibrating together without cancelling each other out. The best word he found to define this transitory condition is "convalescent" - a term he was so fond of that he used it to describe Zarathustra's condition after the disturbing experience of the eternal recurrence. Far from being an abstract, theoretical concept, this is an autobiographical, corporeal word which describes a real experience, and with which Nietzsche portrays a human being in constant movement, no longer sick but not yet completely healed, without a stable existential condition. He is halfway between sickness and health, in such a way that he constantly remembers "both the proximity of winter and the victory that is being won over winter itself". In convalescence, adds Jaspers, Nietzsche recalls the inspiring power of suffering, looking at good health through the eye of a sick man and, vice versa, at sickness through the eyes of a healthy man. The convalescent does not forget his journey from sickness to good health, because he knows he may fall ill again. While he still feels the pain of the "horrible oppression left behind", which he "endured patiently", at the same time he is already anticipating the "thrill of healing" and is "suddenly overcome by the hope of good health" (GS, Preface for the second edition, 1; Z, III, Der Genesende).

\section{UNS VERTIEFT / DELVING DEEPER}

Because of his encounter with suffering, Nietzsche was well "aware of the advantages that my erratic health gives me overall burly minds" and of the "inexhaustible benefit" that he has been able to draw from his "time of severe 
illness". Thought should not be used to acquire a cold, abstract intellectual and pseudo-scientific understanding of suffering, or to justify it by encaging it in the fine net of rationality. This is the habit of "thinking frogs, objectifying, and registering devices with frozen innards". It is not a question of thinking about suffering. Again, in the preface of Die fröhliche Wissenschaft, Nietzsche completely overturns the relationship: it is not thought that follows the experience of suffering, in an attempt to understand it or justify it, but "thoughts themselves that are constantly generated by the suffering". By attributing to them this suffering "motherhood", they will no longer appear disincarnate and abstract, but will be "endowed with blood, heart, fire, pleasure, passion, torment, consciousness, destiny, fate". These are painful thoughts, indeed, but thoughts that help man to feel alive and experience the fullness of existence because they are born of the "constant transformation into light and flame of all that we are". They are living, incarnate thoughts, more essentially human thoughts (GS, Preface for the second edition, 3).

The experience of suffering appears to Nietzsche as indispensable for human existence. Often, he says, "we are tempted to wonder whether we can do without it". At the same time, nobody likes to suffer, and we continuously strive to devise new ways of "opposing pain: pride, derision, willfulness, and withdrawal into the nothingness of Nirvana, the abandonment and oblivion of the self". The fact is, however, that these expedients are unable to silence the cry of suffering. It abandons its romantic, uplifting function, almost as if there were a need for men to become morally more upright and irreprehensible. Marco Vozza emphasises how Nietzsche does not want to come away from his experience of suffering from an attitude of complacent, narcissistic superiority. Suffering does not involve any moralistic redemption, nor does it have any cathartic function: "it does not free" man "from terror", nor "purify him from a dangerous passion", says Nietzsche, controversially echoing "Aristotle" (GS, Vorrede zur zweiten Ausgabe, 3; TI, Was ich den Alten verdanke, 5; cf. Vozza, 2001, 225).

To him suffering means something different, something much closer to what Lou Salomé says in reference to Nietzsche’s experience: "a completely new way of seeing" reality that causes "everything to take on a new flavour" (Andreas-Salomé, 2009, pp. 24-25). This is what Nietzsche calls "great suffering", which unleashes all its disruptive flow on the human being, "helping him to see clear-sighted, in the moment of utmost torment, inside himself" and allowing "his vision to reach far down into the bottomless abyss". "I doubt", exclaims Nietzsche, "that this great suffering 'makes us better,' yet 
I know that it delves deep (uns vertieft) within us". Suffering causes us to penetrate uns vertieft, in the twofold sense highlighted by Leonardo Casini, based on the original German, of delving deep down and, at the same time, making us deeper. It slowly carves deep into the human being, thus allowing him to explore his most secret and tragic darker areas so that he might rise to the surface with a new awareness (GS, Preface for the second edition, $3 ; D$, 114; cf. Casini, 1990, 281; cf. Bizzotto, 1981, pp. 48-51, 53-54).

\section{Suffering. THe MASTER OF SUSPICION}

The man who descends into the cavern of his interiority must watch out for one of the most insidious dangers that can occur when dealing with suffering, which risks imprisoning him in the subterranean world of the subject. This is a challenging obstacle to overcome. Nietzsche adverts us against it because almost spontaneously, "all suffering tends to cause him to turn in on himself" and transform his condition into a withstanding first-hand experience. Indeed, "what we suffer most deeply and personally is incomprehensible and inaccessible to almost everyone else". This "omnipotent pride which allows suffering to be endured" cocoons man egocentrically within himself: "with too much violence and for too long it makes it personal". Jaspers also, analyzing in detail Nietzsche's illness and its influence on his philosophical work, points out that, as one of the various existential dangers, suffering drives forceful thought towards interiority. "The pride of the sick man", reviles Nietzsche "rears up like never before" (GS, 338; UF, 19741877, 44 [9]; D, 114; cf. Jaspers, 1996, 115-116).

The only "antidote" to this centralized drifting, according to Nietzsche, is "alienation and depersonalization". Through the experience of "pain", the "tormented" human being who "suffers acutely" must come out of himself and learns to "see, with terrible coldness, the things that are outside". "Suffering", which leads "to the supreme disenchantment" of the world in which man dwells, is "the only way he can be wrested from the deceptive illusions and dangerous fantasies in which he has lived up to that time. Only this suffering is the extreme liberator of the spirit, the master of the great suspicion" (GS, Preface for the second edition, $3 ; D, 114$ ).

Suffering takes us by the hand and brings us to the school of suspicion, which teaches us not so much how to strengthen our identity as how to unhinge it by demolishing all our idols and certainties. "The plow of evil" 
breaks and overturns, creating the disillusionment that forces man to make a clean sweep of all his comfortable compromises and masks, knocking him off-center and forcing him to accept conversion. This "long, slow pain that takes its time and in which we are burned, as it were, over green wood, forces us to descend into our ultimate depths and put aside all trust, everything good-natured, veiling, mild, average..”.. In Nietzsche's eyes, it is “the strongest and most evil spirits" which have "done the most to advance humanity: time and again they rekindled the dozing passions, (...) reawakened the sense of comparison, of contradiction, of delight in what is new, daring, unattempted; (...) by toppling boundary stones”, all landmarks “on which man's humanity once perhaps rested" and which today suffering is forcing him to put behind him once and for all (GS, Preface for the second edition, 3; GS, 4).

While overthrowing all mythology of omnipotence and immortality, suffering pulls the human being forcefully out of his centralized state; it makes him think about his finitude and look beyond his ego. Vozza tells us that in Nietzsche, the experience of suffering reveals the inadequacy of one's own person and disrupts the monolithic compactness of the ego. It becomes the stimulating condition of critical and genealogical thinking that undermines every position gained and every established totality. In Ecce homo, Nietzsche confesses autobiographically that "my sickness gave me the right to a complete reversal of all my habits" and "slowly freed me". It allowed him to "return to myself, "aware that "never as in the most painful periods of my life, at the height of my illness, have I felt so much happiness". From this slow and exhausting struggle, man "comes back reborn and transmuted, with a different skin", "as if he had lived through something extraordinary and come to know something new and different compared to before". This is an auroral, almost initiatory knowledge; now, in fact, "everything to which the gaze is directed shines with a new light" (EH, 'Menschliches, Allzumenschliches,' 4; D, 114; GS, Preface for the second edition, 4; cf. Vozza, 2003, pp. 236-237; cf. Vozza, 2001, pp. 222-223).

Nietzsche seeks to teach us that once the journey of pain is undertaken, there is no turning back. This journey always ends by "making one a different man, with a few more uncertainties and, above all, with the will to ask, from then on, more questions, deeper, more rigorous, tougher, badder and more silent, than one has ever asked before" (GS, Preface for the second edition, 3).

In Nietzsche's philosophy, hermeneutic suffering causes "man to roll from the center towards an x", transforming all his certainties into uncertainties. 
It does not give answers to the meaning of "life", but from it constantly regenerates questions. Scored by suffering, human existence ceases to be something objective, of itself, pure and becomes uncertain, doubtful, problematic. It is no longer a guarantee, but "itself becomes a problem" (GS, Preface for the second edition, 3; UF, 1970-1974, 2 [127]; cf. Casini, 1990, pp. 280-281; cf. Senigaglia, 2011, p. 90; cf. Manzi, 2005, pp. 572-577).

\section{REFERENCES}

Andreas-Salomé, L. (1894). Friedrich Nietzsche in seinen Werken, Dresden. Carl Reikner.

Aurenque, D. (2013). "Über Nietzsches medizinische Deutung der Moral. Das Leiden als Ursprung der Moralität bei Schopenhauer und Nietzsche", in AA. VV. Moralkritik bei Schopenhaner und Nietzsche, Würzburg. Königshausen \& Neumann.

Bizzotto, M. (1981). Male, sofferenza, malattia. Saggi sul dolore, Camilliani.it. Verona.

Casini, L. (1990). La riscoperta del corpo. Schopenhaner, Fenerbach, Nietzsche. Roma. Studium.

Colli, G. (1980). Scritti su Nietzsche, Milano. Adelphi.

Deleuze, G. (1992). Nietzsche e la filosofia, Milano. Feltrinelli.

FallicA, A. (2002). "La malattia di Nietzsche", in AA. VV. Filosofare con Nietzsche. Roma. FERV.

Fazio, D. (2009). "Postfazione”, in Andreas-Salomé, L. Friedrich Nietzsche. Milano. SE.

Janz, C.P. (1994). Friedrich Nietzsche. Biographie. Frankfurt a.M. Buchengilde Gutemberg.

JaSPERS, K. (1996). Nietzsche. Introduzione alla comprensione del suo filosofare. Milano. Mursia.

Losurdo, D. (2004). Nietzsche, il ribelle aristocratico. Biografia intellettuale e bilancio critico, Torino. Bollati Boringhieri.

Mann, T. (1948). Nietzsches Philosophie im Lichte unserer Erfahrung, Berlin, Suhrkamp.

Manzi, A. (2005). "Il tema della malattia in Nietzsche. Interpretazioni e valutazioni”. Rivista di Teologia dell'Evangelizzazione, 9.

Nietzsche, F. (1967). Menschliches, Allzumenschliches I, II. Berlin. De Gruyter.

NieTzsche, F. (1968). Also sprach Zarathustra. Berlin. De Gruyter.

Nietzsche, F. (1968). Jenseits von Gut und Böse. Berlin. De Gruyter.

NieTzsche, F. (1968). Zur Genealogie der Moral, Berlin. De Gruyter. 
Nietzsche, F. (1969). Der Antichrist, Berlin. De Gruyter.

Nietzsche, F. (1969). Ecce homo. Berlin. De Gruyter.

Nietzsche, F. (1969). Götzen-Dämmerung, Berlin. De Gruyter.

Nietzsche, F. (1970-1974). Nachgelassene Fragmente (Herbst 1885 bis Anfang Januar 1889). Berlin - New York. De Gruyter.

Nietzsche, F. (1971). Morgenröthe. Berlin - New York. De Gruyter.

Nietzsche, F. (1971). Nachgelassene Fragmente (Anfang 1880 bis Frühjahr 1881), Berlin - New York. De Gruyter.

Nietzsche, F. (1972). Die Geburt der Tragödie. Berlin - New York.

Nietzsche, F. (1973). 'Die Philosophie im Tragischen Zeitalter der Griechen', in Nachgelassene Schriften 1870-1873. Berlin - New York. De Gruyter.

Nietzsche, F. (1973). Die fröhliche Wissenschaft. Berlin - New York. De Gruyter.

Nietzsche, F. (1974-1977). Nachgelassene Fragmente (Juli 1882 bis Herbst 1885), Berlin - New York. De Gruyter.

Nietzsche, F. (1975). Briefwechsel, II/5. Berlin - New York. De Gruyter.

Nuccitelli, G. (1996). Il contagio filosofico. L'odissea ideativa di Nietzsche attraverso la lunga infermità. Milano. Guerini.

Schipperges, H. (1975). Am Leitfaden des Leibes. Zur Anthropologetik und Therapeutik Friedrich Nietzsches. Stuttgart. Klett.

Schipperges, H. (1985). Homo patiens. Zur Geschichte des kranken Menschen. München - Zürich. Piper.

Semerari, F. (1993). Il gioco dei limiti. L'idea di esistenza in Nietzsche. Bari. Dedalo.

Senigaglia, C. (2011). "Schmerz, Krankheit, Genesung. Nietzsches Überlegungen zwischen Wissenschaft und Ethik", in AA. VV. Nietzsche. Sein Denken und dessen Entwicklungspotentiale, Neu-Isenburg, Lenz.

Vozza, M. (2001). Esistenza e interpretazione. Nietzsche oltre Heidegger. Roma. Donzelli.

VozZA, M. (2003). “La «grande salute» e l'ottica binoculare di Nietzsche”, in AA. VV. Nietzsche. Illuminismo. Modernità. Firenze. Olschki. 
